\title{
Impact of the occurrence of herbs and weeds on variations in meadow sward economic value
}

\author{
Wpływ występowania ziół i chwastów \\ na zróżnicowanie wartości gospodarczej runi łąk
}

\author{
Mieczysław Grzelak ${ }^{1}$, Eliza Gawet' ${ }^{2}$ Jerzy Barszczewski ${ }^{3}$
}

\section{Summary}

The investigations carried out in 2008-2010 concerned plant communities in the Noteć Leniwa River valley characterised by high and even outstanding natural values and of high valorisation class (IXD, VIII, V, IVB and IIIA). They occur in marshy (High-sedge rushes), strongly wet (Areas with moss and Semi-natural wet) and moderately wet (Purple moor grass and Cnidium meadows or Semi-natural fresh) sites. Mean proportions of herbs and weeds in the sward of these communities are very high and range from $15.9 \%$ up to even $86.1 \%$. The economic value of these communities varies depending on their floristic composition. Hay yields differ and range from 3.1 to $6.5 \mathrm{t} / \mathrm{ha}$, while the sward fodder value (SFV) - from 2.6 to 7.2 .

Key words: herbs and weeds, economic value, meadow sward, natural values

\section{Streszczenie}

Badania wykonane w latach 2008-2010 dotyczą zbiorowisk w dolinie rzeki Noteci Leniwej o dużych, a nawet wybitnych walorach przyrodniczych i o wysokiej klasie waloryzacyjnej: IXD, VIII, V, IVB i IIIA. Występują one w siedliskach bagiennych (Szuwary wielkoturzycowe), silnie wilgotnych (Mechowiska i Półnaturalne łąki wilgotne) oraz umiarkowanie wilgotnych (Łąki trzęślicowe i selernicowe i Półnaturalne łąki siedlisk świeżych). Średni udział ziół i chwastów w runi tych zbiorowisk jest bardzo wysoki i wynosi od $15,9 \%$ do aż 86,1\%. Wartość gospodarcza zbiorowisk w zależności od składu florystycznego jest zróżnicowana. Plon siana wynosi 3,1 do $6,5 \mathrm{t} / \mathrm{ha}$, a wartość użytkowa runi, Lwu = 2,6 do 7,2.

Słowa kluczowe: zioła i chwasty, wartość gospodarcza, ruń łąkowa, walory przyrodnicze

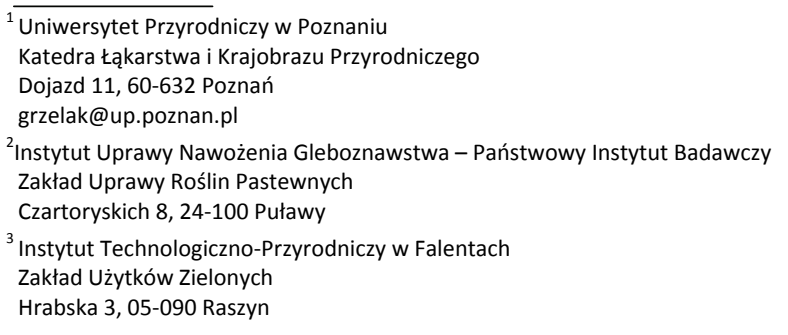




\section{Wstęp / Introduction}

Zarówno poziom, jak i wartość gospodarcza runi łąk zależy od składu florystycznego zbiorowisk łąkowych (Kostuch 1995; Grzelak 2010). Szczególnie ruń siedlisk cennych przyrodniczo, związanych $\mathrm{z}$ prowadzeniem ekstensywnej gospodarki łąkowo-pastwiskowej, składa się z wielu gatunków traw, motylkowatych, turzycowatych oraz ziół i chwastów. Pojawienie się w runi roślin dwuliściennych jest w dużym stopniu zjawiskiem naturalnym, wynikającym ze zmian sukcesyjnych w zbiorowiskach roślinnych (Grime 2001). Zioła i chwasty jako cenne komponenty wielogatunkowych zbiorowisk roślinnych, wpływają przede wszystkim na wartość gospodarczą runi, ale także na ich walory przyrodnicze, biocenotyczne i krajobrazowe (Willby i wsp. 2001). Poszczególne gatunki różnią się wymaganiami siedliskowymi (Wasilewski 2006; Kaczmarek i wsp. 2010). Na ich zróżnicowanie florystyczne wpływa także intensywność i sposób użytkowania (Kamiński i Chrzanowski 2007).

Celem przeprowadzonych badań było wykazanie wpływu występowania ziół i chwastów na zróżnicowanie wartości gospodarczej runi łąk, jako odbicia zróżnicowanych warunków wilgotnościowych, a także ocena plonowania, wartości użytkowej runi i walorów przyrodniczych wytypowanych zbiorowisk.

\section{Materiały i metody / Materials and methods}

Badania wpływu występowania ziół i chwastów na zróżnicowanie wartości gospodarczej runi łąk wykonano w latach 2008-2010, na łąkach cennych przyrodniczo, położonych w dolinie rzeki Noteci Leniwej, na obszarze
Natura 2000. Wyróżniono zbiorowiska na podstawie „Dokumentacji przyrodniczej siedliskowej”, zawartej w rozporządzeniu rolno-środowiskowym dokumentacji przyrodniczej. Rozporządzenie to określa jednostki fitosocjologiczne oraz typy siedlisk dla poszczególnych wariantów. Dla wariantu siedliskowego wyznaczono działki RSS (działki siedliskowe), jednolite pod względem fizjonomii, warunków siedliskowych i roślinności, na których wykonano 91 zdjęcia fitosocjologiczne metodą Braun-Blanqueta.

W zbiorowiskach określono udział (\%) grup roślin w masie plonu, różnorodność florystyczną, a wyróżnione zbiorowiska łąkowe zostały poddane waloryzacji przyrodniczej, w której przeprowadzono ocenę walorów przyrodniczych w oparciu o liczby waloryzacji przyrodniczej (Lwp) według Oświta (2000). Ponadto dla poszczególnych zbiorowisk oszacowano plon suchej masy oraz wyliczono wartość użytkową wytypowanych zbiorowisk według liczb wartości użytkowej (Lwu) (Filipek 1973).

\section{Wyniki i dyskusja / Results and discussion}

Badane zbiorowiska posiadają zróżnicowaną ocenę walorów przyrodniczych. Dwa $\mathrm{z}$ badanych zbiorowisk posiadają duże, a nawet wybitne walory przyrodnicze, o klasie waloryzacyjnej IXD i VIII, dwa średnio i umiarkowane, o klasie waloryzacyjnej $\mathrm{V}$ i IVB, a jedno zbiorowisko, małe o klasie IIIA (tab. 1). O ich ocenie decyduje bogactwo flory oraz osobliwości przyrodniczych z grupy ziół i chwastów. Zdaniem Oświta (2000), o walorach przyrodniczych nie decyduje liczba gatunków, ale ich wartość przyrodnicza, np. gatunek chroniony, rzadki, czy też zagrożony wyginięciem.

Tabela 1. Klasyfikacja zbiorowisk roślinnych według walorów przyrodniczych na tle zróżnicowania siedlisk

Table 1. Classification of plant communities according to natural values set against the background of site variability

\begin{tabular}{|c|c|c|c|c|c|}
\hline $\begin{array}{l}\text { Zbiorowisko } \\
\text { Community }\end{array}$ & $\begin{array}{c}\text { Liczba zdjęć } \\
\text { fitosocjolo- } \\
\text { gicznych } \\
\text { Number of phyto- } \\
\text { sociological photos }\end{array}$ & $\begin{array}{l}\text { Siedlisko } \\
\text { wilgotnościowe } \\
\text { Wetland habitat }\end{array}$ & $\begin{array}{c}\text { Średni udział } \\
\text { ziół i chwastów } \\
\text { Mean share } \\
\text { of herbs } \\
\text { and weeds } \\
{[\%]}\end{array}$ & $\begin{array}{c}\text { Klasa } \\
\text { waloryzacyjna } \\
\text { Valorization } \\
\text { class }\end{array}$ & $\begin{array}{l}\text { Walory } \\
\text { przyrodnicze } \\
\text { Naturalistic } \\
\text { valorization }\end{array}$ \\
\hline $\begin{array}{l}\text { Szuwary wielkoturzycowe } \\
\text { High-sedge rushes }\end{array}$ & 14 & $\begin{array}{l}\text { bagienne } \\
\text { swampy }\end{array}$ & 15,9 & IIIA & $\begin{array}{l}\text { małe } \\
\text { small }\end{array}$ \\
\hline $\begin{array}{l}\text { Mechowiska } \\
\text { Areas with moss }\end{array}$ & 9 & $\begin{array}{l}\text { silnie wilgotne } \\
\text { strongly moist }\end{array}$ & 77,8 & IXD & $\begin{array}{c}\text { wybitne } \\
\text { excellence }\end{array}$ \\
\hline $\begin{array}{l}\text { Łąki trzęślicowe } \\
\text { i selernicowe } \\
\text { Purple moor grass } \\
\text { and Cnidium meadows }\end{array}$ & 16 & $\begin{array}{l}\text { wilgotne } \\
\text { moist }\end{array}$ & 86,1 & VIII & $\begin{array}{l}\text { bardzo duże } \\
\text { very high }\end{array}$ \\
\hline $\begin{array}{l}\text { Półnaturalne łąki wilgotne } \\
\text { Semi-natural wet } \\
\text { meadows }\end{array}$ & 28 & $\begin{array}{c}\text { umiarkowanie } \\
\text { wilgotne } \\
\text { moderately moist }\end{array}$ & 33,3 & V & $\begin{array}{c}\text { średnio } \\
\text { umiarkowane } \\
\text { mean moderate }\end{array}$ \\
\hline $\begin{array}{l}\text { Półnaturalne łąki siedlisk } \\
\text { świeżych } \\
\text { Semi-natural fresh } \\
\text { meadows }\end{array}$ & 24 & $\begin{array}{c}\text { umiarkowanie } \\
\text { wilgotne } \\
\text { moderately moist }\end{array}$ & 38,5 & IVB & $\begin{array}{l}\text { umiarkowane } \\
\text { moderate }\end{array}$ \\
\hline
\end{tabular}


Tabela 2. Wartość użytkowa oraz udział grup roślin w masie plonu w badanych zbiorowisk roślinnych

Table 2. Fodder value and proportions of plant groups in bulk yields in the examined plant communities

\begin{tabular}{|c|c|c|c|c|c|c|c|}
\hline \multirow[b]{2}{*}{$\begin{array}{l}\text { Zbiorowisko } \\
\text { Community }\end{array}$} & \multirow{2}{*}{$\begin{array}{l}\text { Plon siana } \\
\text { Yield } \\
\text { of hay } \\
\text { [t/ha] }\end{array}$} & \multirow[b]{2}{*}{$\begin{array}{l}\text { Lwu* } \\
\text { FVS }\end{array}$} & \multicolumn{4}{|c|}{$\begin{array}{c}\text { Udział grup roślin w masie plonu [\%] } \\
\text { Percentage share of plant group in yield [\%] }\end{array}$} & \multirow[b]{2}{*}{$\begin{array}{l}\text { Wartość runi } \\
\text { Value of sward }\end{array}$} \\
\hline & & & $\begin{array}{c}\text { zioła } \\
\text { i chwasty } \\
\text { herbs and } \\
\text { weeds }\end{array}$ & $\begin{array}{l}\text { trawy } \\
\text { grasses }\end{array}$ & $\begin{array}{l}\text { bobowate } \\
\text { legumes }\end{array}$ & $\begin{array}{l}\text { turzyce } \\
\text { i sity } \\
\text { sedges and } \\
\text { rushes }\end{array}$ & \\
\hline $\begin{array}{l}\text { Szuwary } \\
\text { wielkoturzycowe } \\
\text { High-sedge rushes }\end{array}$ & $5,7-8,2$ & 2,6 & $4,0-27,8$ & $8,9-17,9$ & $0,2-0,45$ & $56,2-82,2$ & $\begin{array}{l}\text { uboga } \\
\text { poor }\end{array}$ \\
\hline $\begin{array}{l}\text { Mechowiska } \\
\text { Areas with moss }\end{array}$ & $2,4-3,8$ & 3,4 & $62,4-93,2$ & $2,9-11,9$ & $0,8-6,6$ & $4,8-17,4$ & $\begin{array}{l}\text { uboga } \\
\text { poor }\end{array}$ \\
\hline $\begin{array}{l}\text { Łąki trzéślicowe } \\
\text { i selernicowe } \\
\text { Purple moor grass and } \\
\text { Cnidium meadows }\end{array}$ & $3,5-4,7$ & 6,4 & $79,4-92,8$ & $2,1-6,9$ & - & $6,2-11,9$ & $\begin{array}{l}\text { dobra } \\
\text { good }\end{array}$ \\
\hline $\begin{array}{l}\text { Półnaturalne łąki } \\
\text { wilgotne } \\
\text { Semi-natural wet }\end{array}$ & $4,2-6,6$ & 6,3 & $16,9-49,7$ & $42,7-77,9$ & $0,8-5,8$ & $0,6-5,4$ & $\begin{array}{l}\text { dobra } \\
\text { good }\end{array}$ \\
\hline $\begin{array}{l}\text { Półnaturalne łąki } \\
\text { siedlisk świeżych } \\
\text { Semi-natural fresh }\end{array}$ & $3,9-5,8$ & 7,2 & $18,9-58,1$ & $32,9-76,7$ & $2,1-6,1$ & $1,7-7,9$ & $\begin{array}{l}\text { dobra } \\
\text { good }\end{array}$ \\
\hline
\end{tabular}

*Lwu - liczba wartości użytkowej runi według Filipka (1973) - FVS - fodder value score index according to Filipek (1973)

Zbiorowiska występują w siedliskach bagiennych (Szuwary wielkoturzycowe), silnie wilgotnych (Mechowiska i Półnaturalne łąki wilgotne) oraz umiarkowanie wilgotnych (Łąki trzęślicowe i selernicowe oraz Półnaturalne łąki siedlisk świeżych). Największym udziałem ziół i chwastów w runi, wykazywały się zbiorowiska z siedlisk silnie wilgotnych i wilgotnych (tab. 1). Średni udział ziół i chwastów w runi tych zbiorowisk jest bardzo wysoki i wynosi od 78,8 do 86,1\%. Wyjątkiem są zbiorowiska szuwarów wielkoturzycowych o charakterze niemal jednogatunkowych agregacji, gdzie zioła i chwasty stanowią zaledwie $15,9 \%$. W zbiorowiskach umiarkowanie wilgotnych, średni udział ziół i chwastów wynosił od 33,3 do $38,5 \%$.

O dużej zależności składu florystycznego zbiorowiska od warunków siedliska, a szczególnie warunków hydrologicznych, świadczą badania Kostucha (1995), Trzaskoś i wsp. (2002), Wasilewskiego (2006) oraz Kaczmarka i wsp. (2010).

Plon siana w poszczególnych zbiorowiskach był zróżnicowany (tab. 2). W mechowisku wynosił zaledwie $2,4-3,8 \mathrm{t} /$ ha, a udział ziół i chwastów wynosił $62,4-93,2 \%$. Wartość gospodarcza runi była uboga, mimo jej wybitnych walorów przyrodniczych. Ubogą wartość runi posiadało również zbiorowisko szuwarów wielkoturzycowych, ponieważ w jego runi nie stwierdzono gatunków cennych przyrodniczo. Plon siana wynosił 5,7-8,2 t/ha, przy udziale ziół i chwastów wynoszącym zaledwie 4,0-27,8\%, co potwierdzają badania Grzelaka (2010). Bardzo wysoki udział ziół i chwastów w runi występował ponadto w bogatym florystycznie zbiorowisku łąk trzęślicowych oraz selernicowych i wynosił od 79,4 do 92,8\%. Plon siana z kolei wynosił 3,5-4,7 t/ha. W pozostałych omawianych zbiorowiskach, uzyskane plony siana wynosiły około 5,0 t/ha.

Wyliczona liczba wartości użytkowej runi (Lwu) według Filipka (1973), wynosiła od 2,6 do 7,2 i nie była zależna od składu florystycznego (tab. 2). Wartość użytkowa runi łąkowo-pastwiskowej zależy nie tylko od składu florystycznego, ale zdaniem Wyłupek (2001) oraz Trzaskoś i wsp. (2002) jest wypadkową oddziaływania warunków hydrologicznych, glebowych i intensywności użytkowania. Potwierdzają to również badania Kamińskiego i Chrzanowskiego (2007). Podobne wyniki dotyczące plonowania i wartości gospodarczej runi łąk podaje Miazga i Mosek (2001).

\section{Wnioski / Conclusions}

1. Zioła i chwasty wpływają na wartość gospodarczą runi oraz na walory przyrodnicze wielogatunkowych zbiorowisk trawiastych.

2. Duże walory przyrodnicze reprezentowały zbiorowiska występujące w siedliskach silnie wilgotnych i mokrych, a największą różnorodnością florystyczną odznaczały się siedliska bagienne, wilgotne i umiarkowanie wilgotne.

3. Na wartość gospodarczą (użytkową i plonowanie) runi łąk duży wpływ miał zarówno procentowy udział ziół i chwastów, jak i udział innych grup roślin w zbiorowisku. 


\section{Literatura / References}

Filipek M. 1973. Projekt kwalifikacji siedlisk łąkowych i pastwiskowych na podstawie liczb wartości użytkowej. Post. Nauk Rol. 4: 59-68.

Grime J.P. 2001. Plant Strategies, Vegetation Processes and Ecosystem Properties. John Wiley, Chichester, UK, 456 pp.

Grzelak M. 2010. Wartość gospodarcza biomasy szuwarów wielkoturzycowych z ekologicznych użytków zielonych. J. Res. Appl. Agric. Engin. 55 (3): 95-98.

Grzelak M., Bocian T. 2006. Zróżnicowanie geobotaniczne zbiorowisk seminaturalnych doliny Noteci Bystrej oraz ich rola w krajobrazie. Ann. UMCS 61, Sec. E: 257-266.

Kaczmarek Z., Grzelak M., Gajewski P. 2010. Warunki siedliskowe oraz różnorodność florystyczna ekologicznych siedlisk przyrodniczych w Dolinie Noteci. J. Res. Appl. Agric. Engin. 55 (3): 142-147.

Kamiński J., Chrzanowski S. 2007. Wpływ użytkowania kośnego i pastwiskowego na właściwości fizyczne gleb oraz skład florystyczny zbiorowisk roślinnych na zmeliorowanym torfowisku. Woda Środowisko Obszary Wiejskie 7 (2b) (21): 75-86.

Kostuch R. 1995. Przyczyny występowania różnorodności florystycznej ekosystemów trawiastych. Ann. UMCS, Sec. E, 50, Suppl.: $23-32$.

Miazga S., Mosek B. 2001. Wartość gospodarcza łąk w dolinie Wyżnicy. Zesz. Probl. Post. Nauk Rol. 479: 203-208.

Oświt J. 2000. Metoda przyrodniczej waloryzacji mokradeł i wyniki jej zastosowania w wybranych obiektach. Instytut Melioracji i Użytków Zielonych, Falenty: 3-32, 36 ss.

Trzaskoś M., Czyż H., Kitczak T. 2002. Skład florystyczny i walory przyrodnicze łąk śródleśnych na tle warunków wodnych. Rocz. AR Poznań 342, Melioracje i Inżynieria Środowiska: 77-484.

Wasilewski Z. 2006. Ocena jakości runi i darni spasanych użytków zielonych w różnych siedliskach. Woda Środowisko Obszary Wiejskie 6 (1) (16): 413-421.

Willby N.J., Pygott J.R., Eaton J.W. 2001. Inter-relationships between standing crop, biodiversity and trait attributes of hydrophytic vegetation in artificial waterways. Freshw. Biol. 46: 883-902.

Wyłupek T. 2001. Plonowanie i wartość użytkowa łąk w dolinie Poru. Pam. Puł. 125: 175-182. 